\title{
Pengukuran Beban Kerja Mental Karyawan di Lantai Produksi Karet Setengah Jadi Dengan Metode Nasa TLX (Taskload Index)
}

\section{Mufrida Meri. Z, Fandi Ahmad}

\author{
Program Studi Teknik Industri, Universitas Ekasakti Padang \\ J1. Veteran 26B Padang Sumatera Barat \\ Email : mufridameri@gmail.com
}

\begin{abstract}
Ergonomics is the science, art and application of technology to harmonize or balance between all facilities used both in activity and rest with all the abilities, abilities and limitations of humans both physically and mentally so as to achieve a better overall quality of life. In addition to physical workload, mental workload must also be assessed. However, assessing mental workload is not as easy as assessing physical workload. The National Aeronautics and Space Administration Task Load Index (NASA-TLX) method is a method used to evaluate fundamental workloads. There are 6 factors that influence Psychological workload, namely Mental Demand, Physical Demand, Temporal Demand, Own Performance, Frustation, and Effort. The most dominant factor affecting the value of mental workload lies in the indicator of Mental Demand (Mental Needs). Overall mental workload of employees reached 57.28 employees experiencing mental workload pressure with a high category.
\end{abstract}

Keywords: ergonomics, nasa-tlx, mental burden, psychological.

\begin{abstract}
Abstrak
Ergonomi adalah ilmu, seni dan penerapan teknologi untuk menyerasikan atau penyeimbangan antara segala fasilitas yang digunakan baik dalam beraktivitas maupun istirahat dengan segala kemampuan, kebolehan dan keterbatasan manusia baik secara fisik maupun mental sehingga dicapai suatau kualitas hidup secara keseluruhan yang lebih baik. Selain beban kerja fisik, beban kerja yang bersifat mental harus pula dinilai. Namun demikian penilaian beban kerja mental tidaklah semudah menilai beban keraja fisik. Metode National Aeronautics and Space Administration Task Load Index (NASA-TLX) adalah metode yang digunakan untuk mengevaluasi beban kerjamental. Terdapat 6 faktor yang mempengaruhi beban kerja Psikologis yaitu Mental Demand, Physical Demand, Temporal Demand, Own Perfomance, Frustation, dan Effort. Faktor yang paling dominan yang mempengaruhi terhadap nilai beban kerja mental terletak pada indikator Mental Demand (Kebutuhan Mental). beban kerja mental karyawan keseluruhan mencapai 57,28 karyawan mengalami tekanan beban kerja mental dengan kategori tinggi.
\end{abstract}

Katakunci: ergonomi, nasa-tlx, beban mental, psikologis. 


\section{PENDAHULUAN}

Aktivitas manusia dapat dibagi menjadi dua golongan, yaitu kerja fisik (otot) dan kerja mental (otak). Walaupun tidak dapat dipisahkan, namun masih dapat dibedakan pekerjaan dengan dominasi aktifitas fisik dan pekerjaan dengan dominasi aktivitas mental. Aktivitas fisik dan mental ini menimbulkan konsekuensi, yaitu munculnya beban kerja. Beban kerja merupakan perbedaan antara kemampuan pekerja dengan tuntutanpekerjaan.

Apabila kemampuan dari pekerja lebih tinggi dari pada tuntutan pekerjaan maka akan menimbulkan rasa bosan dan sebaliknya, apabila kemampuan pekerja lebih rendah dari pada tuntutan pekerjaan maka akan menimbulkan dampak kelelahan yang berlebih yang menyebabkan stress kerja pada karyawan dan menyebabkan sering terjadinya kecelakaan kerja dan kecacatan produk. Hal ini menyebabkan keuntungan perusahaan berkurang. Pabrik karet PT Batang Hari Barisan merupakan pabrik khusus pengolahan karet setengah jadi untuk dijual didalam negeri dan luar negeri untuk dijadikan barang jadi. Berdasarkan datapermintaan produk karet setengah jadi di ketahui semakin tinggi, maka proses produksi karet setengah jadi pun di tingkatkan dan jam kerja karyawan ditambah, karyawan memiliki beban kerja yang tinggi serta tanggung jawab lebih untuk bisa memenuhi target produksi dan jaminan mutu produk yang berkualitas. Dampak beban kerja yang terjadi akibat tekanan-tekanan dari atasan yaitu karyawan mengalami stress, dan juga karyawan merasa terbebani dalam melakukan pekerjaan karena tekanan mental sehingga dapat menyebabkan kecelakan kerja padakaryawan.

Manfaat dari penelitian dengan menggunakan metode NASA-TLX untuk mengetahui tingkat beban kerja mental karyawan bagian lantai produksi karet setengah jadi, sehingga kedepannya perusahaan dapat mengetahui penyebab dan gejala beban kerja yang dirasakan oleh karyawan bagian lantai produksi sehingga dapat meningkatkan produktivitas karyawan dalam bekerja serta dapat meningkatkan kualitas mutu dan produksi karet setengah jadi di PT Batang Hari Barisan.

\subsection{Beban Kerja Mental}

Selain beban kerja fisik, beban kerja yang bersifat mental harus pula dinilai. Namun demikian penilaian beban kerja mental tidaklah semudah menilai beban kerja fisik. Pekerjaan yang bersifat mental sulit diukur memalui perubahan fungsi fatal tubuh. Secara fisiologis, aktivitas mental terlihat sebagai suatu jenis pekerjaan yang ringan sehingga kebutuhan kalori untuk aktivitas mental juga lebih rendah. Padahal secara moral dan tanggung jawab, aktivitas mental jelas lebih berat dibandingkan dengan aktivitas fisik karena lebih melibatkan kerja otak (White-Collar) dari pada kerja otot (Blue-Collar).

\subsection{NASA-TLX}

The NASA Task Load Index merupakan suatu prosedur pembobotan dan ranting multidimensional yang menyediakan suatu penilaian beban kerja secara keseluruhan yang didasarkan pada rerata ranting dari enam (6) sub-skala, yaitu: Mental Demands, physical Demands, Temoral Demands, Own Performance, Effort, and Frustation. Dapat dilihat pada tabel di bawah ini :

Tabel 1. Penjelasan Dimensi Skala Ranting / Skor Metode NASA-TLX

\begin{tabular}{clll}
\hline No & Dimensi & \multicolumn{1}{c}{ Deskripsi } & $\begin{array}{c}\text { Skala } \\
\text { Rating }\end{array}$ \\
\hline 1. & Tuntutan & Seberapa besar & Rendah \\
Mental & tuntutan aktivitas & / tinggi \\
(Mental & mental dan & \\
Demand) & $\begin{array}{l}\text { perseptual yang } \\
\text { dibutuhkan dalam }\end{array}$ & (High/ & Low) \\
& pekerjaan (contoh: & \\
& berpikir, \\
& memutuskan, & \\
& menghitung, & \\
& mengingat, \\
& melihat, mencari). & \\
& Apakah pekerjaan & \\
& tersebut mudah & \\
& atau sulit,
\end{tabular}


sederhana atau

kompleks, longgar

atau ketat?

2. Tuntutan

Fisik

(Physical

Demand)

Seberapa besar

aktivitas fisik

yang dibutuhkan

dalam pekerjaan.

Apakah pekerjaan

tersebut mudah

atau sulit, pelan

atau cepat, tenang

atau buru-buru?

3. Tuntutan

Waktu

(Temporal

Demand)

Seberapa besar

tekanan waktu

Rendah

Rendah

/ tinggi

(High/

Low)

yang dirasakan

selama pekerjaan

atau elemen

(High/

pekerjaan

berlangsung?

Apakah pekerjaan

perlahan dan

sanatai, atau cepat

dan melelahkan?

4. Performan Seberapa besar

si $(O w n$

keberhasilan

Performan didalam mencapai

ce)

target pekerjaan?

Seberapa puas

performansi

didalam mencapai

target tersebut?

5. Tinggkat

Usaha

(Effort)

Seberapa besar uasaha yang

dikeluarkan secara

mental dan fisik

yang dibituhkan

untuk mencapai

level performansi?
6. Tingkat

Frustasi

(Frusta

tion)

Seberapa besar

tidak aman, putus

asa, tersinggung,

stres, dan

terganggudibandin

$\mathrm{g}$ dengan perasaan

aman,puas, cocok,

nyaman, dan

kepuasandiri yang

dirasakan selama

Sumber: Tarwaka, 2015

Tingkat dari masing-masing ke enam (6) faktor yang menyumbangkan beban kerja pada pekerjaan tertantu harus dievaluasi dengan
JUTI-UNISI (Jurnal Tenik Industri UNISI) menggunakan ranting, ditentukan dengan responden mereka terhadap komparasi di antara ke enam faktor tersebut. Ranting pada masingmasing sub- skala didapatkan setelah performansi pekerjaan atau segmen pekerjaan.

The NASA Task Load Index suatu prosedur untuk mengevaluasi 2 bagian yaitu: Pembobotan (weights)' dan 'Penskoran (rating)'.

\subsection{Pembobotan (Weights)}

Pada bagian ini responden dimita untuk memberi tanda centang pada salah satu kolom dari dua indikator yang dirasakan lebih dominan menimbulkan beban kerja terhadap pekerjaan tersebut. Kueisioner NASA-TLX yang diberikan berupa perbandingan berpasangan. Persyaratan pertama adalah bahwa masing-masing penskoran digunakan untuk mengevaluasi kontributor masing- masing faktor terhadap beban kerja pada pekerjaan tertentu. Penghitungan pembobotan dari dua sumber yang potensial antara variabelitas penskoran yaitu; perbedaan didalam definisi beban kerja antara penskoran didalam pekerjaan, dan perbedaan sumber beban kerja antara pekerjaan. Sebagai tambahan, pembobotan itu sendiri menyediakan informasi diagnostik tentang beban kerja yang diankibatkan oleh pekerjaan.

Dalam metode ini terdapat kemungkinan 15 pasang komporasi (pair wise-comparasion) dari 6 skala dapat dilihat pada tabel 2 di bawah ini

Tabel 2. Pasangan Kartu untuk Evaluasi Beban Kerja (source-of-workload evaluation)

(High/
Low)
Rendah
/ tinggi
(High/
Low)

\begin{tabular}{|lllll|}
\hline 1. $\square$ & Tingkat Usaha & atau & $\square$ & Performansi \\
2. $\square$ & Tuntutan Waktu & atau & $\square$ & Tingkat Frustasi \\
3. $\square$ & Tuntutan Waktu & atau & $\square$ & Tingkat Usaha \\
4. $\square$ & Tuntutan Fisik & atau & $\square$ & Tingkat Frustasi \\
5. $\square$ & Performansi & atau & $\square$ & Tingkat Frustasi \\
6. $\square$ & Tuntutan Fisik & atau & $\square$ & Tuntutan Waktu \\
7. $\square$ & Tuntutan Fisik & atau & $\square$ & Performansi \\
8. $\square$ & Tuntutan Waktu & atau & $\square$ & Tuntutan Mental \\
9. $\square$ & Tingkat Frustasi & atau & $\square$ & Tingkat Usaha \\
10. $\square$ & Performansi & atau & $\square$ & Tuntutan Mental \\
11. $\square$ & Performansi & atau & $\square$ & Tuntutan Waktu \\
12. $\square$ & Tuntutan Mental & atau & $\square$ & Tingkat Usaha \\
13 $\square$ & Tuntutan Mental & atau & $\square$ & Tuntutan Fisik \\
14 $\square$ & Tingkat Usaha & atau & $\square$ & Tuntutan Fisik \\
15 $\square$ & Tingkat Frustasi & atau & $\square$ & Tuntutan Mental \\
\hline
\end{tabular}

Sumber: Tarwaka, 2015 
Masing-masing pasangan ditampilkan pada sebuah kartu. Subjek diminta untuk melingkari anggota kartu dari masing-masing pasangan yang menyumbangkan lebih banyak beban kerja akibat pekerjaan yang dilakukan. Selanjutnya, jumlah waktu dari masing-masing faktor yang dipilihdijumlahkan.

\subsection{Pemberian Ranting (Rating)}

Persyaratan kedua adalah untuk memperoleh nilai ranting dari setiap skala yang merefleksikan faktor pada pekerjaan yang dibebankan pada subjek. Selanjutnya, skala ditampilkan pada lembar rating (rating sheet) seperti pada Tabel 3 dibawah ini

Tabel 3. Lembar Kerja Penskoran (Ranting)

\begin{tabular}{|c|c|c|}
\hline Indikator & Pertanyaan & Ranting Nilai \\
\hline $\begin{array}{l}\text { Kebutuhan Mental } \\
\text { (Mental Demand) }\end{array}$ & 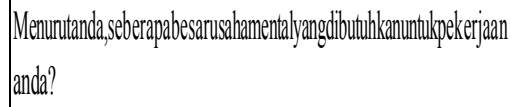 & \\
\hline $\begin{array}{l}\text { Kebutuhan Fisik } \\
\text { (Physical Demand) }\end{array}$ & 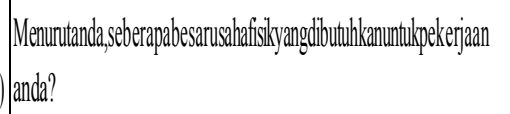 & \\
\hline $\begin{array}{l}\text { Kebutuhan Waktu } \\
\text { (Temporal Demand }\end{array}$ & $\begin{array}{l}\text { Menuruttandasseberapabesartekananyangandarasakakanberkatiandengan } \\
\text { waktuuntukmelakukanpekerjaananda? }\end{array}$ & \\
\hline $\begin{array}{l}\text { Performansi Kerija } \\
\text { (Own Performance) }\end{array}$ & $\begin{array}{l}\text { Menurutanda,Seberapabesartingkatkeberthasilanandadalammelakukan } \\
\text { pekerjaananda? }\end{array}$ & \\
\hline $\begin{array}{l}\text { Tingkat Frustasi } \\
\text { (Frustation) }\end{array}$ & $\begin{array}{l}\text { Menurutanda,seerapapbesarkecemasan,perassantekanan, danstressang } \\
\text { andararasakanberkaitandenganwaktuuntukmelakukanpekerjaananda? }\end{array}$ & \\
\hline $\begin{array}{l}\text { TingkatUsaha } \\
\text { (Effort) }\end{array}$ & 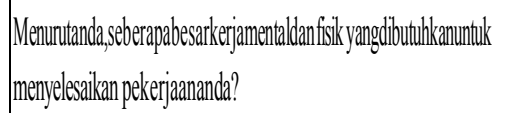 & \\
\hline
\end{tabular}

Sumber: Tarwaka, 2015

Skor beban kerja keseluruhan untuk masingmasing subjek dihitung dengan mengalikan setiap rating dengan bobot (Weights) yang diberikan terhadap faktor oleh subjek yang bersangkutan. Selanjutnya total rating pembobotan (The Sum of the Weights Rating) untuk setiap pekerjaan dibagi dengan 15 (jumlah pembobotan - The Sum of Weights) dapat dilihat pada tabel dibawah ini (Tarwaka, 2015), rumus yang digunakan:
JUTI-UNISI (Jurnal Tenik Industri UNISI)

a. Mengukur Produk

$$
\text { Produk }=\text { Ranting } \times \text { Bobot faktor }
$$

Produk didapat dari hasil pengalian antara rating yang dilakukan pada tahap awal dengan bobot faktor pada tahap kedua.

b. Mengukur Weighted Workload (WWL) dengan cara

$$
\mathrm{WWL}=\sum \text { produk }
$$

Setelah mengukur produk, dilanjutkan dengan mengukur beban kerja terukur. Nilai yang didapat adalah hasi dari penjumlahan produk.

c. Mengukur rata-rata WWL

$$
\text { Rata-rata WWL }=\frac{W W}{15}
$$

Setelah mengukur beban kerja terukur, maka langkah selanjutya adalah mengukur ratarata beban kerja yang mana jumlah produk tersebut dibagi 15.

\section{METODELOGI PENELITIAN}

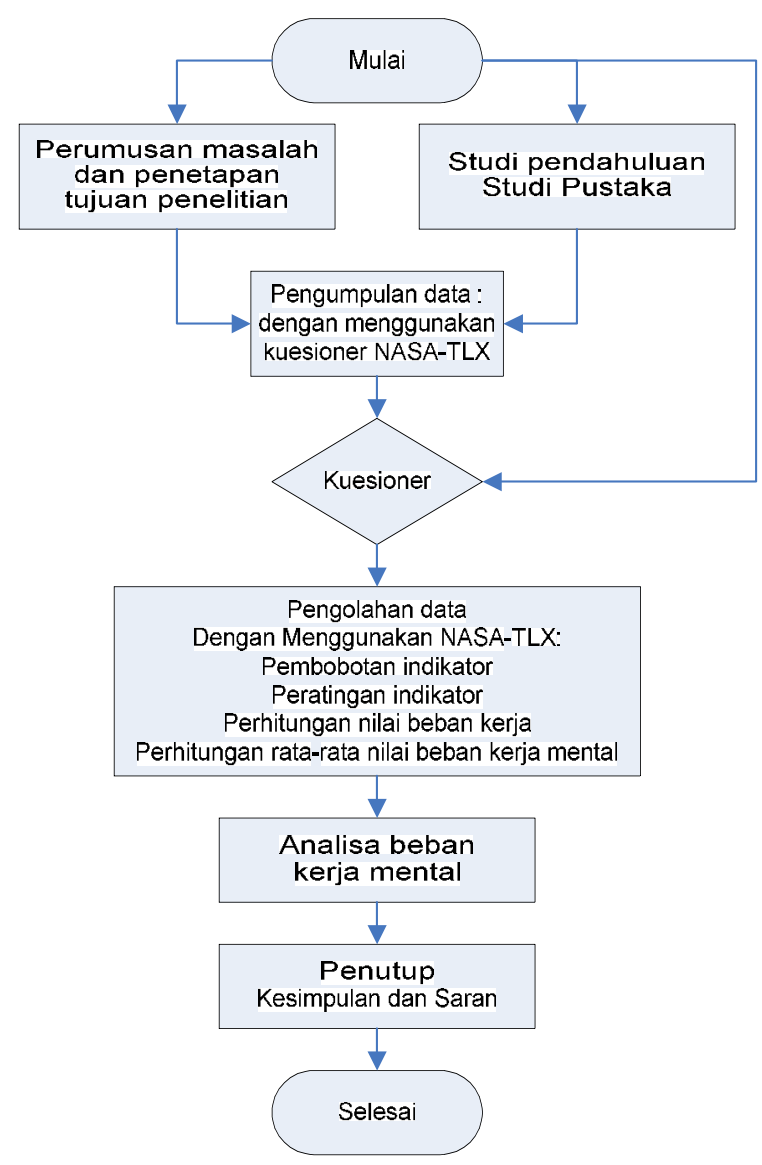




\section{HASIL DAN PEMBAHASAN}

3.1. Data Pembobotan

Pengumpulan data hasil penyebaran kueisioner NASA-TLX terhadap karyawan lantai produksi, berikut hasil data pembobotan penyebaran kueisioner:

\section{Tabel 4. Hasil Pembobotan}

\begin{tabular}{|c|c|c|c|c|c|c|c|c|c|c|c|c|c|}
\hline \multirow{3}{*}{$\mathbb{N}_{0}$} & \multicolumn{13}{|c|}{ Indikator } \\
\hline & & & & & & & & & & & & & PK \\
\hline & & & & & & & & & & & & $\mathrm{U}$ & $\mathrm{F}$ \\
\hline Nurral & KM & KM P & & $\mathrm{U}$ & $\mathrm{TF} \mathrm{K}$ & & & $\mathrm{KF}$ & $\mathrm{KW}$ & & TF & & PK \\
\hline Muham & KM & & & $\mathrm{U}$ & $\mathrm{KM} \mathrm{K}$ & & $\mathrm{K}$ & KF & $\mathrm{KW}$ & & TF & & PK \\
\hline \begin{tabular}{|l|l|}
3 & Yogi \\
\end{tabular} & KM & $\overline{\mathrm{KW}}$ & & $\mathrm{U}$ & TF 1 & $\mathrm{~F} \mid \mathrm{K}$ & $\begin{array}{ll}\mathrm{F} F \\
\end{array}$ & TF & PK & & $\mathrm{KW}$ & $\overrightarrow{\mathrm{PK}} \mathrm{P}$ & $\mathrm{PK}$ \\
\hline \begin{tabular}{l|l|}
4 & Ardan \\
\end{tabular} & KM & & & KM & $\overline{T F} \mathrm{~K}$ & & $\mathrm{Ku}$ & $\mathrm{KF}$ & PK & & TF & 01 & PK \\
\hline 5 Nanda & $\mathrm{KF}$ & $\overline{\mathrm{KM} \mathrm{K}}$ & $\mathrm{IM} \mathrm{K}$ & $\mathrm{KM}$ & $\overline{\mathrm{MM}} \mathrm{I}$ & & $\mathrm{K}$ & $\mathrm{KF}$ & PK & & $\mathrm{KW}$ & $\mathrm{U} \mid \mathrm{P}$ & PK \\
\hline 6 Rahmmad & KM & $\overline{K M ~ K ~}$ & & $\mathrm{U}$ & $\overline{\mathrm{KM} K \mathrm{~K}}$ & $\overline{N / K}$ & \begin{tabular}{|l|l}
$\mathrm{F}$ & $\mathrm{KF}$ \\
\end{tabular} & $\mathrm{KF}$ & PK & & TF & UlP & $\mathrm{PK}$ \\
\hline 7 Amsal & KM & KM K K & IM & $\mathrm{U}$ & $\mathrm{KM} \mathrm{K}$ & W/ K & $\mathrm{F} U$ & $\mathrm{KF}$ & PK & & $\mathrm{KW}$ & $\mathrm{PK} \mid \mathrm{P}$ & $\mathrm{PK}$ \\
\hline 8 Dinul & $\mathrm{KF}$ & KM P & & $\mathrm{MM}$ & $\overline{\mathrm{MM} K \mathrm{~K}}$ & & $\mathrm{KF}$ & TF & $\mathrm{KW}$ & & $\mathrm{KW}$ & $\mathrm{U} / \mathrm{P}$ & \begin{tabular}{l|l}
$\mathrm{PK}$ & $\mathrm{U}$ \\
\end{tabular} \\
\hline 9 Sakdan & $\mathrm{KF}$ & KM K K & $\mathrm{IM} \mathrm{K}$ & $\mathrm{KM}$ & $\langle\mathrm{M}$ & $F \mid \mathrm{F}$ & $\mathrm{K}$ KF & $\mathrm{KF}$ & PK & $\mathrm{KW}$ & TF & $\mathrm{U} \mid \mathrm{P}$ & \begin{tabular}{l|l} 
PK & TF \\
\end{tabular} \\
\hline 10 Arman 1 & KM & KM P & & $\mathrm{U}$ & $\angle M$ & & $\mathrm{KF}$ & $\mathrm{KF}$ & PK & & $\mathrm{KW}$ & & \begin{tabular}{l|l} 
PK & U \\
\end{tabular} \\
\hline Wahyul & KM & $\mathrm{KW} / \mathrm{K}$ & $\mathrm{KM} \mathrm{K}$ & $\mathrm{KM}$ & $\mathrm{KM} \mathrm{I}$ & & $\mathrm{K}$ & $\mathrm{KF}$ & $\mathrm{KW}$ & & $\mathrm{KW}$ & & \begin{tabular}{l|l}
$\mathrm{PK}$ & $\mathrm{U}$ \\
\end{tabular} \\
\hline 12 Zainal Ab & KM & KM P & & $\mathrm{U} 1$ & $\langle\mathrm{M}$ & & $\mathrm{K}$ KF & $\mathrm{KF}$ & PK & $\mathrm{KW}$ & TF & & \begin{tabular}{l|l} 
PK & U \\
\end{tabular} \\
\hline 13 Nurzoli & KM & KM K K & & $\mathrm{U}$ & TF 1 & $\mathrm{FK}$ & $\mathrm{FU}$ & $\mathrm{KF}$ & $\mathrm{KW}$ & $D^{2}$ & TF & & \begin{tabular}{l|l}
$\mathrm{PK}$ & $\mathrm{U}$ \\
\end{tabular} \\
\hline 14 Yussizal & KM & KM P & & $\mathrm{U}$ & TF 1 & F & $\mathrm{K}$ & $\mathrm{KF}$ & $\mathrm{KW}$ & $\mathrm{KW}$ & $\mathrm{KW}$ & & PK \\
\hline 15 Adifitra & KM & $\mathrm{KW} / \mathrm{P}$ & $\mathrm{K} K \mathrm{~K}$ & $\mathrm{KM}$ & $\mathrm{KM} \mathrm{K}$ & 1 & $\mathrm{~F}$ KF & TF & PK & $\mathrm{KW}$ & TF & $\mathrm{PK}$ & \begin{tabular}{l|l} 
TF & U \\
\end{tabular} \\
\hline \begin{tabular}{l|l}
16 & Abdul Ra
\end{tabular} & $\mathrm{KF}$ & $\overline{\mathrm{KM} \mathrm{K}}$ & $\mathrm{IM}$ & U & $\angle M$ & $\mathrm{FK}$ & $\mathrm{F} U$ & $\mathrm{KF}$ & $\mathrm{KW}$ & U & TF & $\mathrm{PK} \mid \mathrm{P}$ & \begin{tabular}{l|l|} 
PK & TF \\
\end{tabular} \\
\hline 17 Hendri & KM & $\mathrm{KM} P \mathrm{P}$ & \begin{tabular}{l|l} 
PK & K
\end{tabular} & $\mathrm{KM}$ & $\mathrm{KM} \mathrm{I}$ & & $\mathrm{FF}$ & $\mathrm{KF}$ & PK & v & $\mathrm{KW}$ & & $\begin{array}{ll}\text { PK } & \text { TF } \\
\end{array}$ \\
\hline 18 Pandriant & $\mathrm{KF}$ & \begin{tabular}{l|l|l}
$\mathrm{KW}$ \\
\end{tabular} & KM & $\mathrm{U}$ & $\mathrm{KM} \mathrm{I}$ & & $\mathrm{KKF}$ & $\mathrm{KF}$ & $\mathrm{KW}$ & $\mathrm{KW}$ & TF & $\mathrm{U} \mid \mathrm{T}$ & $\begin{array}{ll}\text { TF } & \text { Th } \\
\end{array}$ \\
\hline \begin{tabular}{l|l}
19 & Supriadi \\
\end{tabular} & KM & $\mathrm{KW} / \mathrm{P}$ & PK & $\mathrm{U} 1$ & $\mathrm{KM} \mathrm{I}$ & 1 & $\mathrm{KKF}$ & $\mathrm{KF}$ & PK & $\mathrm{KW}$ & TF & $\mathrm{U} \mid \mathrm{P}$ & $\begin{array}{ll}\text { PK } & \text { Th } \\
\end{array}$ \\
\hline \begin{tabular}{l|l|l}
20 Harianto \\
\end{tabular} & $\mathrm{KF}$ & $\overline{\mathrm{KM} \mathrm{K}}$ & KM & U & $\mathrm{TF} \mathrm{K}$ & & $\mathrm{F} F$ & $\mathrm{KF}$ & $\mathrm{KW}$ & & TF & $\mathrm{PK} \mid \mathrm{T}$ & $\begin{array}{lll}T F & U \\
\end{array}$ \\
\hline 21 Andika & $\mathrm{KF}$ & KM K K & $\mathrm{KM} \mathrm{K}$ & $\mathrm{KM}$ & $\overline{\mathrm{MM}} \mathrm{I}$ & $\mathrm{F} P \mathrm{P}$ & $\mathrm{KKF}$ & $\mathrm{KF}$ & $\mathrm{KW}$ & $\mathrm{KW}$ & $\mathrm{KW}$ & $\mathrm{PK}$ & \begin{tabular}{l|l} 
TF & $U$ \\
\end{tabular} \\
\hline 22 Ade Sap & KM & KM P & $\mathrm{PK} \mathrm{K}$ & $\mathrm{KM}$ & $\mathrm{TF} 1$ & & $\mathrm{~K} K \mathrm{KF}$ & TF & PK & 1 & $\mathrm{KW}$ & $\mathrm{U} \mid \mathrm{P}$ & $\begin{array}{ll}\text { PK } & \text { Th } \\
\end{array}$ \\
\hline \begin{tabular}{|l|l|}
23 & Ucok \\
\end{tabular} & $\mathrm{KF}$ & $\mathrm{KW} / \mathrm{K}$ & KM & $\mathrm{U} 1$ & $\mathrm{KMK}$ & $\mathrm{W} / \mathrm{P}$ & $\mathrm{KKF}$ & $\mathrm{KF}$ & $\mathrm{KW}$ & U & $\mathrm{KW}$ & $\mathrm{U} / \mathrm{P}$ & $\begin{array}{lll}\text { PK } & \text { TH } \\
\end{array}$ \\
\hline \begin{tabular}{l|l|}
24 & Afria \\
\end{tabular} & KM & $\mathrm{KW} / \mathrm{K}$ & KM & $\mathrm{U}$ & $\mathrm{KM} \mathrm{I}$ & & $\mathrm{F} F$ & TF & PK & $\mathrm{KW}$ & TF & $\mathrm{U} / \mathrm{P}$ & \begin{tabular}{l|l}
$\mathrm{PK}$ & $\mathrm{U}$ \\
\end{tabular} \\
\hline 25 Gussizal & $\mathrm{KF}$ & $\begin{array}{lll}\mathrm{KW} & \mathrm{P} \\
\end{array}$ & PK & $\mathrm{U} 1$ & $\overline{\mathrm{MM} K \mathrm{~K}}$ & & $\mathrm{KF}$ & $\mathrm{KF}$ & PK & v & $\mathrm{KW}$ & $\mathrm{UTP}$ & $\begin{array}{lll}\mathrm{PK} & \mathrm{U} \\
\end{array}$ \\
\hline 26 Hanif & KM & KM P & PK & U & $\mathrm{TF} 1$ & & $\mathrm{~F} U$ & $\mathrm{KF}$ & $\mathrm{KW}$ & & $\mathrm{KW}$ & $\mathrm{U} / \mathrm{P}$ & \begin{tabular}{l|l} 
PK & $\mathrm{U}$ \\
\end{tabular} \\
\hline 27 Yondrí & KM & \begin{tabular}{ll|l}
$K W$ & $K$ \\
\end{tabular} & $\mathrm{KM}$ & $8 \mathrm{M}$ & $2 \mathrm{MM}$ & & $\mathrm{FKF}$ & $\mathrm{KF}$ & $\mathrm{KWW}$ & U & $\mathrm{KW}$ & U1 & $\begin{array}{ll}\mathrm{PK} & \mathrm{TH} \\
\end{array}$ \\
\hline 28 Irsan & $\mathrm{KM}$ & KM P P & PK & $\mathrm{U} 1$ & $\mathrm{KM}$ & & $\mathrm{FKF}$ & $\mathrm{KF}$ & PK & & $\mathrm{KW}$ & U & $\begin{array}{lll}\text { TF } & \text { TH } \\
\end{array}$ \\
\hline 29 IIIman & $\mathrm{KF}$ & KM K K & KM & U & $\langle\mathrm{MM}$ & & $\mathrm{U}$ & $\mathrm{KF}$ & $\mathrm{KWW}$ & KW & $\mathrm{TF}$ & $\mathrm{PK}$ & $\begin{array}{lll}\text { TF } & U \\
\end{array}$ \\
\hline 30 Rahmad & KM & $\mathrm{KM} \mathrm{K}$ & $\mathrm{KMK}$ & $\overline{\mathrm{MM}}$ & $\overline{\mathrm{SM}} \mathrm{I}$ & & $\mathrm{FKF}$ & $\mathrm{KF}$ & $\mathrm{KW}$ & & $\mathrm{KW}$ & U1 & $\begin{array}{lll}\text { PK } & \text { Th } \\
\end{array}$ \\
\hline \begin{tabular}{|l|l|l}
1 Alhafiz $\mathrm{S}$ \\
\end{tabular} & KM & KM K K & $\mathrm{KM} K$ & $\mathrm{MM}$ & $\langle\mathrm{MM}$ & & $\mathrm{F} K \mathrm{KF}$ & $\mathrm{KF}$ & $\mathrm{KWW}$ & KW & $\mathrm{KW}$ & U1 & $\begin{array}{ll}\text { PK } & \text { Th } \\
\end{array}$ \\
\hline \begin{tabular}{|l|l|l|}
32 & Harun \\
\end{tabular} & $\mathrm{KF}$ & KM K K & $\mathrm{KMK}$ & $\mathrm{MM}$ & $\operatorname{TF} 1$ & & $\mathrm{U}$ & $\mathrm{KF}$ & PK & KW & $\mathrm{TF}$ & $\mathrm{PK}$ & $\begin{array}{lll}P K & \mathrm{U} \\
\end{array}$ \\
\hline 33 Amman & $\mathrm{KM}$ & $\mathrm{KW} / \mathrm{K}$ & $\mathrm{KM} K$ & $\mathrm{MM}$ & $\mathrm{KMK}$ & & $\mathrm{KF}$ & $\mathrm{KF}$ & $\mathrm{KW}$ & & $\mathrm{TF}$ & $\mathrm{PK}$ & $\begin{array}{lll}\mathrm{PK} & \mathrm{U} \\
\end{array}$ \\
\hline 34 Noffi Wer & KM & $\begin{array}{lll}\mathrm{KW} & \mathrm{P} \\
\end{array}$ & $\overline{\mathrm{PK} K \mathrm{~K}}$ & $\mathrm{KM}$ & $\langle\mathrm{M}$ & & $\mathrm{FU}$ & $\mathrm{KF}$ & $\mathrm{KW}$ & KW & $\mathrm{TF}$ & PK & $\begin{array}{lll}\mathrm{PK} & \mathrm{U} \\
\end{array}$ \\
\hline \begin{tabular}{|l|l|l|}
35 & Yusuf \\
\end{tabular} & $\mathrm{KF}$ & $\mathrm{KM} K \mathrm{~K}$ & KM & $\overline{U 1}$ & $\overline{S M K}$ & & $\mathrm{KKF}$ & TF & $\mathrm{KW}$ & & $\mathrm{KW}$ & PK & $\begin{array}{lll}T F & U \\
\end{array}$ \\
\hline \begin{tabular}{l|l}
36 & Benni \\
\end{tabular} & KM & $\overline{\mathrm{KM} P \mathrm{P}}$ & $\overline{\mathrm{PK}} \mathrm{K}$ & $\mathrm{SM}$ & $\overline{\mathrm{MM} \mid \mathrm{I}}$ & & $\overline{F K F}$ & $\mathrm{KF}$ & PK & & $\mathrm{KW}$ & & \begin{tabular}{l|l} 
TF & $U$
\end{tabular} \\
\hline
\end{tabular}

JUTI-UNISI (Jurnal Tenik Industri UNISI) Tabel 5. Hasil Pemberian Ranting

\begin{tabular}{|c|c|c|c|c|c|c|c|}
\hline \multirow[b]{2}{*}{ No } & \multirow[b]{2}{*}{ Nama Karyawan } & \multicolumn{6}{|c|}{ Indikator } \\
\hline & & $\begin{array}{l}\text { Kebutuhan } \\
\text { Mental (KM }\end{array}$ & $\begin{array}{l}\text { Kebutuhan } \\
\text { Fisik (KF) }\end{array}$ & \begin{tabular}{l|l} 
F) & Kebutuhan \\
Faktu (KW)
\end{tabular} & $\begin{array}{l}\text { Performans } \\
\text { Kerja (PK) }\end{array}$ & $\begin{array}{l}\text { Tingkat } \\
\text { Frustasi(TF) }\end{array}$ & Usaha (U) \\
\hline 1 & Nursal & 40 & 50 & 45 & 60 & 60 & 70 \\
\hline 2 & Muhammad Syah & 50 & 55 & 50 & 50 & 70 & 70 \\
\hline 3 & Yogi & 60 & 70 & 55 & 65 & 70 & 75 \\
\hline 4 & Ardan & 55 & 70 & 60 & 50 & 75 & 80 \\
\hline 5 & Nanda & 70 & 60 & 60 & 65 & 60 & 65 \\
\hline 6 & Rahmad & 50 & 55 & 40 & 65 & 50 & 50 \\
\hline 7 & Amsal & 60 & 40 & 50 & 55 & 40 & 45 \\
\hline 8 & Dinul & 40 & 60 & 40 & 55 & 60 & 75 \\
\hline 9 & Sakdan & 40 & 50 & 65 & 60 & 65 & 50 \\
\hline 10 & Arman Taufik & 60 & 65 & 60 & 70 & 65 & 75 \\
\hline 11 & Wahyudi Zainal & 60 & 65 & 50 & 65 & 50 & 70 \\
\hline 12 & Zainal Abidin & 45 & 40 & 60 & 55 & 60 & 65 \\
\hline 13 & Nurzoli & 47 & 50 & 60 & 60 & 50 & 55 \\
\hline 14 & Yussizal & 60 & 40 & 40 & 55 & 30 & 55 \\
\hline 15 & Adifititra & 60 & 40 & 45 & 55 & 40 & 60 \\
\hline 16 & Abdul Rahmad & 70 & 60 & 50 & 40 & 65 & 50 \\
\hline 17 & Hendri Oktavianus & 60 & 55 & 65 & 70 & 60 & 60 \\
\hline 18 & Pandrianto & 50 & 65 & 70 & 75 & 80 & 55 \\
\hline 19 & Supriadi & 70 & 75 & 60 & 80 & 65 & 77 \\
\hline 20 & Harianto & 70 & 76 & 78 & 60 & 75 & 66 \\
\hline 21 & Andika & 72 & 79 & 77 & 60 & 80 & 70 \\
\hline 22 & Ade Saputra & 60 & 66 & 70 & 72 & 71 & 80 \\
\hline 23 & Ucok & 61 & 64 & 65 & 77 & 74 & 60 \\
\hline 24 & Afria & 45 & 50 & 30 & 55 & 40 & 50 \\
\hline 25 & Gussizal & 43 & 65 & 50 & 60 & 65 & 70 \\
\hline 26 & Hanif & 60 & 55 & 60 & 65 & 55 & 50 \\
\hline 27 & Yondri & 42 & 70 & 65 & 60 & 55 & 70 \\
\hline 28 & Irsan & 75 & 50 & 65 & 40 & 55 & 60 \\
\hline 29 & Ilman & 70 & 50 & 45 & 60 & 70 & 65 \\
\hline 30 & Rahmad Fadil & 63 & 69 & 60 & 55 & 50 & 70 \\
\hline 31 & Alhafiz Saputra & 65 & 70 & 55 & 60 & 50 & 70 \\
\hline 32 & Harun & 60 & 68 & 50 & 65 & 50 & 63 \\
\hline 33 & Arman Syah & 50 & 50 & 55 & 60 & 55 & 65 \\
\hline 34 & Nofri Wendo & 30 & 60 & 50 & 40 & 45 & 65 \\
\hline 35 & Yusuf & 70 & 50 & 30 & 60 & 30 & 45 \\
\hline 36 & Benni & 50 & 55 & 60 & 55 & 40 & 70 \\
\hline
\end{tabular}

Dari hasil pengumpulan data kuesioner NASA-TLX lalu dapat dihitung nilai Weighted Workload (WWL) sebagaimana dapat dilihat pada Tabel 6 berikut. Mengukur rata-rata WWL

$$
\text { Rata-rata WWL }=\frac{W W}{15} L
$$


Tabel 6. Perhitungan Nilai Rata-Rata Weighted Workload (WWL)

\begin{tabular}{|c|c|c|c|c|c|c|c|c|c|}
\hline \multirow[b]{2}{*}{ No } & \multirow[b]{2}{*}{ Nama Karyawan } & \multicolumn{6}{|c|}{ Bobot x Rating } & \multirow[b]{2}{*}{$\begin{array}{l}\text { Total } \\
\text { WWL }\end{array}$} & \multirow[b]{2}{*}{ Rata-Rata WWL } \\
\hline & & $\begin{array}{l}\text { Kelutuluana } \\
\text { Mental } \\
\text { (KM) }\end{array}$ & $\begin{array}{l}\text { Kebutuh } \\
\text { n Fisik } \\
(\mathrm{KF})\end{array}$ & $\begin{array}{l}\text { Keboutuha } \\
\text { nWaktu } \\
\text { (KW) }\end{array}$ & $\begin{array}{l}\text { Perfoma } \\
\text { nsikerija } \\
\text { (PK) }\end{array}$ & $\begin{array}{l}\text { Tingkat } \\
\text { Frustasi } \\
\text { (TF) }\end{array}$ & Usaha(U) & & \\
\hline 1 & Nursal & 80 & 150 & 90 & 120 & 120 & 280 & 840 & 56,00 \\
\hline 2 & Muhammad Syah & 150 & 55 & 150 & 200 & 70 & 210 & 835 & 55,67 \\
\hline 3 & Yogi & 120 & 210 & 110 & 195 & 140 & 225 & 1000 & 66,67 \\
\hline 4 & Ardan & 165 & 70 & 120 & 200 & 150 & 240 & 945 & 63,00 \\
\hline 5 & Nanda & 280 & 180 & 60 & 195 & 0 & 260 & 975 & 65,00 \\
\hline 6 & Rahmad & 200 & 165 & 40 & 130 & 50 & 200 & 785 & 52,33 \\
\hline 7 & Amsal & 240 & 80 & 100 & 165 & 0 & 180 & 765 & 51,00 \\
\hline 8 & Dinul & 120 & 120 & 160 & 165 & 60 & 150 & 775 & 51,67 \\
\hline 9 & Sakdan & 160 & 200 & 65 & 180 & 130 & 50 & 785 & 52,33 \\
\hline 10 & Arman Taufik & 180 & 195 & 60 & 350 & 0 & 225 & 1010 & 67,33 \\
\hline 11 & Wahyudi Zainal & 240 & 130 & 150 & 195 & 0 & 210 & 925 & 61,67 \\
\hline 12 & Zainal Abidin & 135 & 120 & 60 & 275 & 60 & 130 & 780 & 52,00 \\
\hline 13 & Nurzoli & 141 & 150 & 120 & 120 & 100 & 165 & 796 & 53,07 \\
\hline 14 & Yussizal & 120 & 80 & 120 & 220 & 30 & 165 & 735 & 49,00 \\
\hline 15 & Adifitita & 180 & 80 & 135 & 165 & 120 & 60 & 740 & 49,33 \\
\hline 16 & Abdul Rahmad & 210 & 240 & 50 & 80 & 130 & 150 & 860 & 57,33 \\
\hline 17 & Hendri Oktavianus & 240 & 220 & 65 & 280 & 60 & 60 & 925 & 61,67 \\
\hline 18 & Pandrianto & 100 & 260 & 210 & 75 & 240 & 110 & 995 & 66,33 \\
\hline 19 & Supriadi & 140 & 225 & 120 & 320 & 130 & 154 & 1089 & 72,60 \\
\hline 20 & Harianto & 140 & 304 & 156 & 60 & 225 & 198 & 1083 & 72,20 \\
\hline 21 & Andika & 288 & 316 & 231 & 120 & 80 & 70 & 1105 & 73,67 \\
\hline 22 & Ade Saputra & 180 & 132 & 140 & 288 & 213 & 80 & 1033 & 68,87 \\
\hline 23 & Ucok & 122 & 192 & 260 & 154 & 74 & 180 & 982 & 65,47 \\
\hline 24 & Afria & 135 & 150 & 60 & 110 & 80 & 150 & 685 & 45,67 \\
\hline 25 & Gussizal & 43 & 195 & 150 & 240 & 0 & 280 & 908 & 60,53 \\
\hline 26 & Hanif & 120 & 165 & 180 & 130 & 55 & 200 & 850 & 56,67 \\
\hline 27 & Yondri & 168 & 280 & 195 & 60 & 55 & 140 & 898 & 59,87 \\
\hline 28 & Irsan & 225 & 150 & 130 & 80 & 110 & 180 & 875 & 58,33 \\
\hline 29 & IIman & 210 & 150 & 90 & 120 & 140 & 195 & 905 & 60,33 \\
\hline 30 & Rahmad Fadil & 189 & 138 & 120 & 165 & 50 & 280 & 942 & 62,80 \\
\hline 31 & Allhafiz Saputra & 325 & 280 & 165 & 60 & 50 & 70 & 950 & 63,33 \\
\hline 32 & Harun & 180 & 204 & 50 & 260 & 100 & 126 & 920 & 61,33 \\
\hline 33 & Arman Syah & 200 & 100 & 165 & 180 & 55 & 130 & 830 & 55,33 \\
\hline 34 & Nofri Wendo & 90 & 180 & 150 & 120 & 45 & 130 & 715 & 47,67 \\
\hline 35 & Yusuf & 210 & 100 & 90 & 120 & 60 & 135 & 715 & 47,67 \\
\hline 36 & Benni & 200 & 220 & 60 & 110 & 40 & 210 & 840 & 56,00 \\
\hline & Total & 6226 & 6186 & 4377 & 6007 & 3022 & 5978 & 31796 & 2119,73 \\
\hline
\end{tabular}

JUTI-UNISI (Jurnal Tenik Industri UNISI)

Tabel 7. Perhitungan Nilai Rata-rata Indikator Beban Kerja

\begin{tabular}{|c|c|c|c|c|c|c|}
\hline Kategori & KM & KF & KW & PK & TF & U \\
\hline Total & 6226 & 6186 & 4377 & 6007 & 3022 & 5978 \\
\hline Rata-rata & 78,91 & 78,65 & 66,16 & 77,50 & 54,97 & 77,32 \\
\hline
\end{tabular}

Gambar 2. Grafik Beban Kerja Dengan Indikator

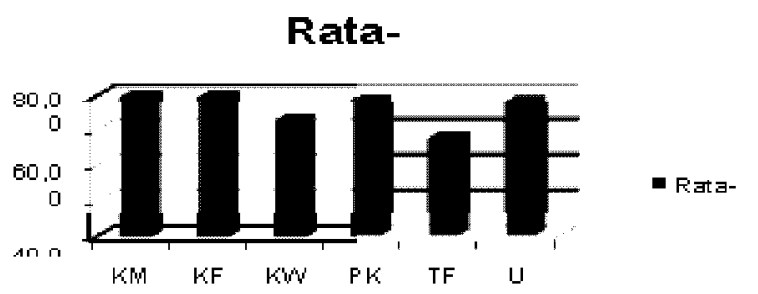

\subsection{Pengkategorian Beban Kerja Mental}

Berikut hasil pengkategorian beban kerja mental karyawan berdasarkan kategori dan skala interval diatas maka kita dapat mengklasifikasikan atau memberikan kategori terhadap beban kerja mental masing-masing karyawan di lantai produksi PT. Batang Hari Barisan. Adapun pengkategorian beban kerja Mental karyawan adalah sebagai berikut:

Tabel 8. Interval Beban Kerja Mental Karyawan

\begin{tabular}{|c|c|c|c|}
\hline No & Nama Karyawan & Skala Interval & Kategori \\
\hline 1 & Afria & 45,67 & Agak Tinggi \\
\hline 2 & Nofri Wendo & 47,67 & Agak Tinggi \\
\hline 3 & Yusuf & 47,67 & Agak Tinggi \\
\hline 4 & Yusrizal & 49,00 & Agak Tinggi \\
\hline 5 & Adifitra & 49,33 & Agak Tinggi \\
\hline 6 & Amsal & 51,00 & Tinggi \\
\hline 7 & Dinul & 51,67 & Tinggi \\
\hline 8 & Zainal Abidin & 52,00 & Tinggi \\
\hline 9 & Sakdan & 52,33 & Tinggi \\
\hline 10 & Rahmad & 52,33 & Tinggi \\
\hline 11 & Nurzoli & 53,07 & Tinggi \\
\hline 12 & Arman Syah & 55,33 & Tinggi \\
\hline 13 & Muhammad Syah & 55,67 & Tinggi \\
\hline 14 & Nursal & 56,00 & Tinggi \\
\hline 15 & Benni & 56,00 & Tinggi \\
\hline 16 & Hanif & 56.67 & Tinggi \\
\hline 17 & Abdul Rahmad & 57,33 & Tinggi \\
\hline 18 & Irsan & 58,33 & Tinggi \\
\hline 19 & Yondri & 59,87 & Tinggi \\
\hline 20 & Ilman & 60,33 & Tinggi \\
\hline 21 & Gusrizal & 60,53 & Tinggi \\
\hline 22 & Harun & 61,33 & Tinggi \\
\hline 23 & Wahyudi Zainal & 61,67 & Tinggi \\
\hline 24 & Hendri Oktavianus & 61,67 & Tinggi \\
\hline 25 & Rahmad Fadli & 62,80 & Tinggi \\
\hline 26 & Ardan & 63,00 & Tinggi \\
\hline 27 & Alhafiz Saputra & 63,33 & Tinggi \\
\hline 28 & Nanda & 65,00 & Tinggi \\
\hline 29 & Ucok & 64,47 & Tinggi \\
\hline 30 & Pandrianto & 66,33 & Tinggi \\
\hline 31 & Yogi & 66,67 & Tinggi \\
\hline 32 & Arman Taufik & 67,33 & Tinggi \\
\hline 33 & Ade Saputra & 68,87 & Tinggi \\
\hline 34 & Harianto & 72,20 & Tinggi \\
\hline 35 & Supriadi & 72,60 & Tinggi \\
\hline 36 & Andika & 73,67 & Tinggi \\
\hline \multicolumn{2}{|r|}{ Jumlah } & 2062,07 & \\
\hline & Rata-rata & 57,28 & Tinggi \\
\hline
\end{tabular}


Tabel 9. Rekapitulasi WWL Karyawan Keseluruhan

\begin{tabular}{|c|c|c|}
\hline Jumlah & rata & Kategori \\
\hline 5 orang & 47,87 & Agak Tinggi \\
\hline 31 orang & 58,8 & Tinggi \\
\hline
\end{tabular}

\section{KESIMPULAN}

Adapaun kesimpulan yang didapat dari penelitian di lantai produksi karet setengah jadi di PT. Batang Hari Barisan adalah sebagai berikut:

1. Berdasarkan analisis data terdapat 6 faktor yang mempengaruhi beban kerja karyawan yaitu Mental Demand, Physical Demand, Temporal Demand, Own Perfomance, Frustation, dan Effort.

2. Faktor yang paling dominan mempengaruhi nilai beban kerja mental yang dialami oleh karyawan di lantai produksi karet setengah jadi di PT. Batang Hari Barisan terletak pada indikator Kebutuhan Mental.

3. Berdasarkan hasil dari perhitungan maka dapat diketahui jumlah karyawan yang memiliki tingkat beban kerja mental kategori agak tinggi dengan rata-rata WWL 47,87 yang berjumlah 5 orang dan kategori tinggi dengan rata-rata WWL 58,8 yang berjumlah 31 orang. Secara umum, rata-rata beban kerja mental karyawan keseluruhan mencapai 57,28 maka dapat disimpulkan bahwa karyawan mengalami tekanan serta beban kerja mental dengan kategori tinggi.

\section{DAFTAR PUSTAKA}

Afma Vera Methalina. 2016. Analisa Beban Kerja Operator Inspeksi Dengan Metode Nasa-Tlx (Task Load Index) Di Pt. Xyz. Jurnal: UniversitasRiau.

Anwar Syamsul dan Mutiara Deli. 2015. Beban Kerja Mental Menurut Level Jabatan dan Usia Karyawan di Industri CPO. Jurnal: Politeknik ATIPadang.

Diniaty Dewi, dan Muliadi Zikri. 2016. Analisis Beban Kerja Fisik Dan Mental Karyawan Pada Lantai Produksi Dipt Pesona Laut Kuning. Jurnal: UIN Sultan Syarif KasimRiau.
JUTI-UNISI (Jurnal Tenik Industri UNISI)

Hardianto Iridiastadi, dan Yassierli. 2014. Ergonomi Suatu Pengantar. Bandung: PT. RemajaRosdakarya.

Muslimah Etika, Dkk. 2015. Efek Musik Terhadap Beban Kerja Mental Pekerja Batik Tulis Di Batik Putra Laweyan. Jurnal: Universitas MuhammadiyahSurakarta.

Ramadhania Nasty dan Parwati Niken, ST, MM. 2015. Pengukuran Beban Kerja Psikologis Karyawan Call Center Menggunakan Metode Nasa-Tlx (Task Load Index) Pada Pt. Xyz. Jurnal: Universitas Al AzharIndonesia.

Susetyo Joko, Dkk. 2012. Pengaruh Beban Kerja Mental Dengan Menggunakan Metode Nasatask Load Iindex (Tlx) Terhadap Stres Kerja. Jurnal: Institut Sains \& Teknologi AKPRIND Yogyakarta.

Umyati Ani, Dkk. 2016. Pengukuran Beban Kerja Mental Pada Divisi Operasi Pt. X Dengan Metode Nasa-Tlx. Jurnal: Universitas Sultan AgengTirtayasa.

Tarwaka. 2015. Ergonomi Industri: Dasar-Dasar Pengetahuan Ergonomi dan Aplikasi di Tempat Kerja. Harapan Press, Surakata. 